\title{
Cytological Analysis of the Reciprocal Hybrids between Low- and High-Chromosome Acipenserids, the Great Sturgeon, Huso huso (L.), and the Russian Sturgeon, Acipenser gueldenstaedtii Brandt
}

\author{
V. A. Arefiev and A. I. Nikolaev \\ Laboratory of Mariculture, All-Union Research Institute of Marine Fisheries and \\ Oceanography (VNIRO), Verh. Krasnoselskaya 17a, Moscow 107140, USSR
}

Accepted April 18, 1991

Karyotype structure of hybrids of crossing between sturgeon species with equal chromosome numbers, i. e. species from the same chromosome groups was examined earlier (Arefjev 1988, 1989, Burtzev et al. 1988, Arefjev and Philippova, unpubl. data). From mean values of quantitative karyotypic parameters hybrids either did not differ from those of the parents or were practically intermediate; disbalancing of hybrid karyotype occurred in various degrees and was accompanied by decrease of fertility and expressed as an increase of variablity of the diploid number and other quantitative karyotypic parameters.

Data on hybridization of fishes under cytogenetic control are meanwhile scarce; so intermediate inheritance of karyotype characters (in particular, the diploid number) appears to be common. The more interesting should be the analysis of situation observed as a result of chromosome set study in the reciprocal hybrids between the Russian sturgeon, Acipenser gueldenstaeditt, and the great sturgeon, Huso huso.

During last 2-3 years cultivation of this hybrid has been intensively mastered in aquaculture of the U.S.S. R. It may be used in ranching programs as well as in cage-rearing both in marine and fresh water due to its easy adaptability to salinity of 16-18\% (Burtzev et al. 1989). Such adaptation does not jeopardize genetic pollution of natural populations due to a priori supposed sterility of hybrids between the great and the Russian sturgeons.

\section{Materials and methods}

The breeders of great sturgeon and Russian sturgeon were caught in the Lower Volga River. The spawning was made artificially and the progeny was reared at the Ikryanynsk fish farm near Astrachan' in 1987. Juveniles (reciprocal hybrids and great sturgeon) at the age of 1.5-2 months were delivered to the Scientific Experimental Marculture Station at Bolshoj Utrish (Krasnodar Region, at the Caucases shore of the Black Sea). Viability of all variants including "pure" species and hybrids was approximately equal.

Four specimens of great sturgeon and twelve of Russian sturgeon and eleven of hybrid aged 3 months (Table 1) were used. Fishes were processed according to the Vasiliev and Sokolov method (1980) with slight modifications (Rivlin et al. 1985): fishes were intramuscularly injected with $0.1 \%$ colchicine ("Serva") solution in the dosage of $0.05-0.1 \mathrm{ml}$ per fish (average fish weight was about $6 \mathrm{~g}$ ). Fish was kept alive for 6-8 hr in 20-1 aquaria with intensive aeration. Tissue of head lymphoid gland was placed into hypotonic solution $(0.4 \%$ $\mathrm{KCl}$ ) for $35 \mathrm{~min}$ and then into cold methanol-acetic acid (3:1) fixative for $1 \mathrm{~min}$ and finally into fresh portion of fixative for $1 \mathrm{hr}$. Preparations were made by air-drying method on clean lipidless slides and stained with $5 \%$ Giemsa solution prepared on standard phosphate buffer $(\mathrm{pH}=6.8)$ for $35 \mathrm{~min}$. 
Metaphase plates were analyzed by light microscopy; their number is shown in Table 1 and magnification scales are presented on microphotos.

Table 1. Quantitative characteristics of karyotypes of the Russian and the great sturgeons and their reciprocal hybrids

\begin{tabular}{|c|c|c|c|c|}
\hline \multirow[b]{2}{*}{ Character } & \multicolumn{4}{|c|}{ Form } \\
\hline & $\begin{array}{l}\text { Russian } \\
\text { sturgeon }\end{array}$ & $\begin{array}{c}\text { Russian } \\
\times \\
\text { great }\end{array}$ & $\begin{array}{c}\text { Great } \\
\times \\
\text { Russian }\end{array}$ & $\begin{array}{l}\text { Great } \\
\text { sturgeon }\end{array}$ \\
\hline No. of fishes & 12 & 7 & 4 & 4 \\
\hline No. of metaphase & & & & \\
\hline plates & 69 & 84 & 41 & 36 \\
\hline $2 \mathrm{n}:$ mode & $246-250$ & $\mathrm{n} / \mathrm{e}^{*}$ & $n / e^{*}$ & $116-117$ \\
\hline$\overline{\mathrm{x}}$ & $249.9 \pm 2.2$ & $167.2 \pm 1.6$ & $169.4 \pm 2.9$ & $117.6 \pm 0.4$ \\
\hline C. V. & $3.9 \%$ & $8.9 \%$ & $11.0 \%$ & $2.7 \%$ \\
\hline MC: mode & $95-96$ & $74-75$ & $n / e^{*}$ & 62 \\
\hline$\overline{\mathrm{x}}$ & $97.6 \pm 0.4$ & $74.0 \pm 0.4$ & $74.2 \pm 0.7$ & $61.2 \pm 0.2$ \\
\hline C. V. & $1.9 \%$ & $4.8 \%$ & $5.9 \%$ & $3.0 \%$ \\
\hline AC: mode & $151-160$ & 91-95 & $n / e^{*}$ & $58-59$ \\
\hline$\overline{\mathrm{x}}$ & $152.2 \pm 2.6$ & $93.0 \pm 1.4$ & $95.3 \pm 2.4$ & $57.6 \pm 0.6$ \\
\hline C. V. & $7.7 \%$ & $14.0 \%$ & $16.2 \%$ & $6.0 \%$ \\
\hline NF: mode & $341-350$ & $231-240$ & $251-260$ & $174-175$ \\
\hline$\overline{\mathrm{x}}$ & $346.1 \pm 2.3$ & $241.3 \pm 1.9$ & $243.6 \pm 3.5$ & $178.2 \pm 0.5$ \\
\hline C. $v$. & $3.1 \%$ & $7.3 \%$ & $9.2 \%$ & $2.2 \%$ \\
\hline
\end{tabular}

* n/e-mode not expressed.

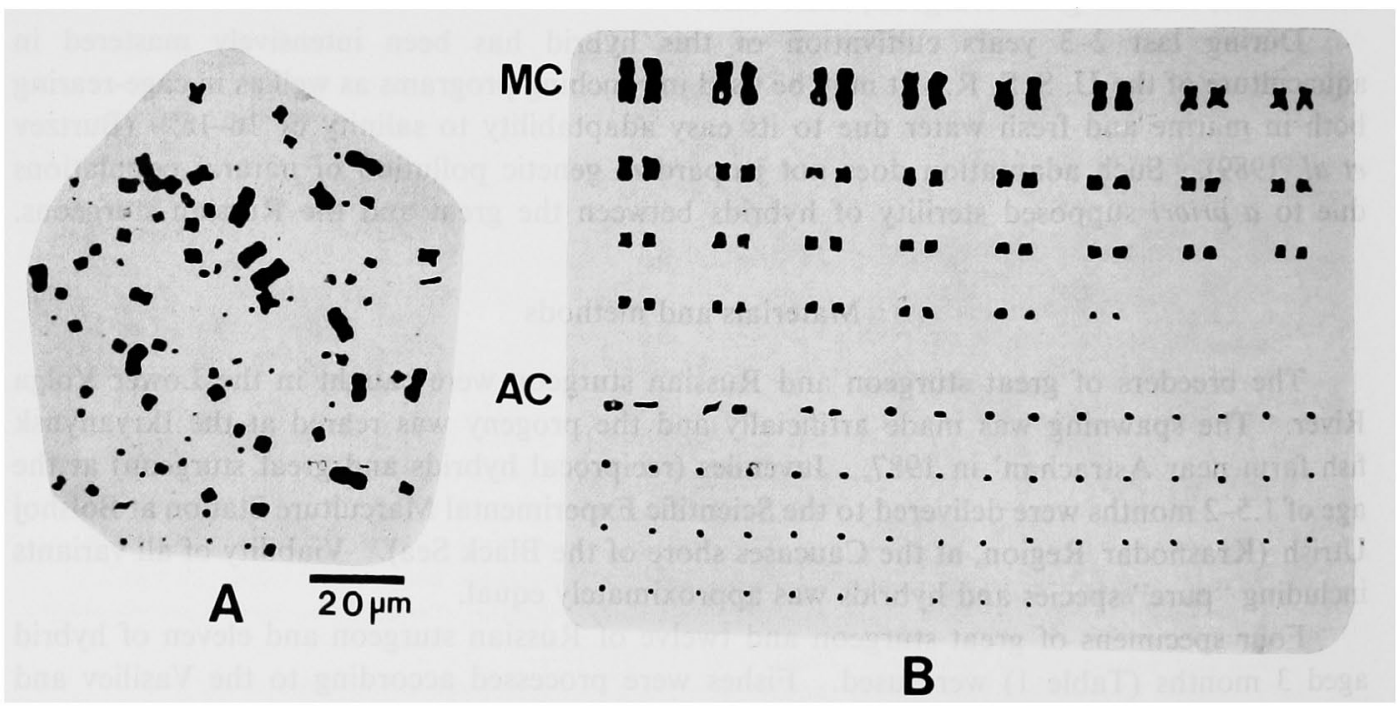

Fig. 1. Metaphase plate (A) and karyogram (B) of great sturgeon: $2 n=118, M C=60$.

\section{Results and discussion}

Karyotype of great sturgeon (Fig. 1) appear to be identical to that of specimens from Italy (Fontana and Colombo 1974) and from the lower Volga River (Vasiliev 1985, Birstein and Vasiliev 1987). Chromosome complement of Russian sturgeon was described earlier (Arefjev 1989b), and karyotypes of the Caspian and the Black Sea populations were found to be com- 
pletely similar. Chromosome sets and karyograms are presented in Figs. 2 and 3.

Hypothetically modal chromosome number in the hybrids would be intermediate, $2 \mathrm{n}=$ $(118+250) / 2=184$. However, as one can see from Table 1 and Fig. 4 the average number of

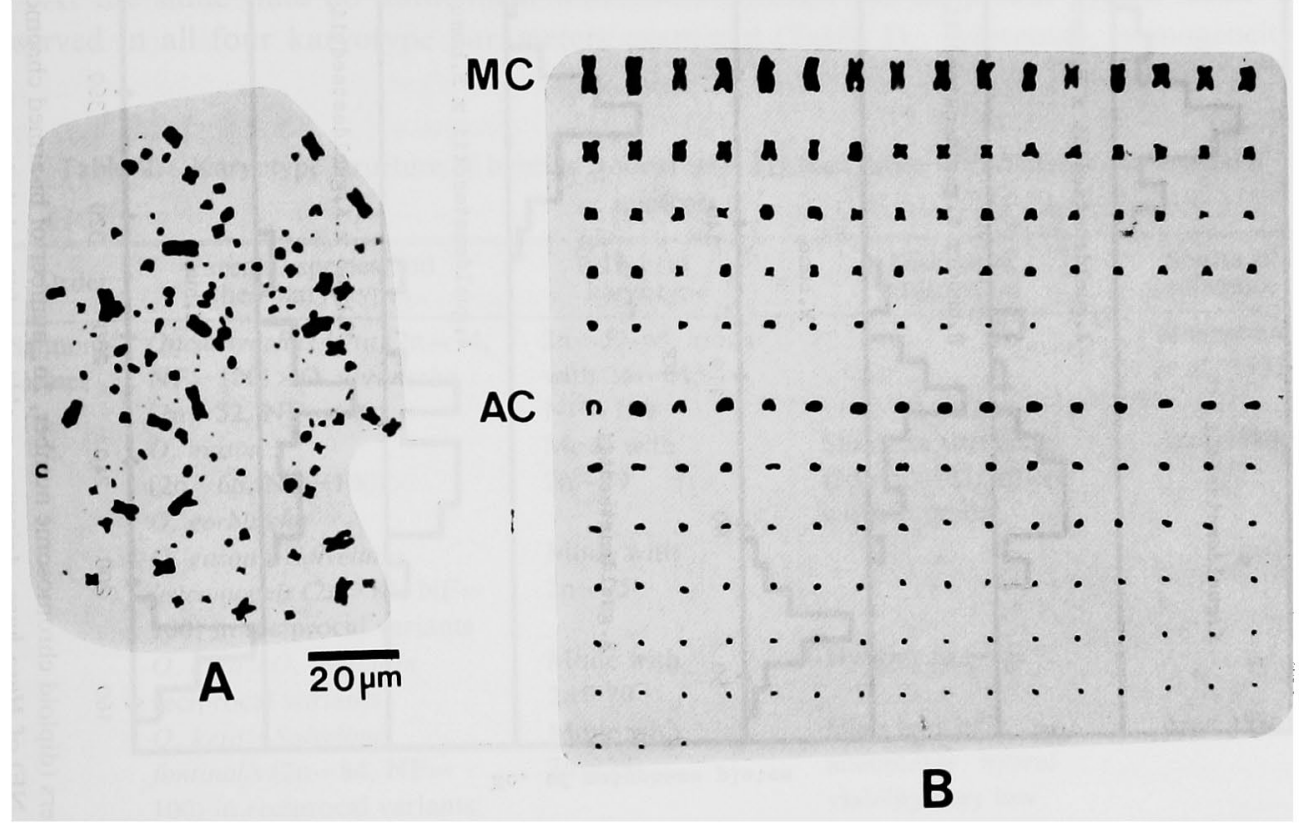

Fig. 2. Metaphase plate (A) and karyogram (B) of hybrid between great sturgeon (female) and Russian sturgeon (male): $2 \mathrm{n}=174, \mathrm{MC}=75$.
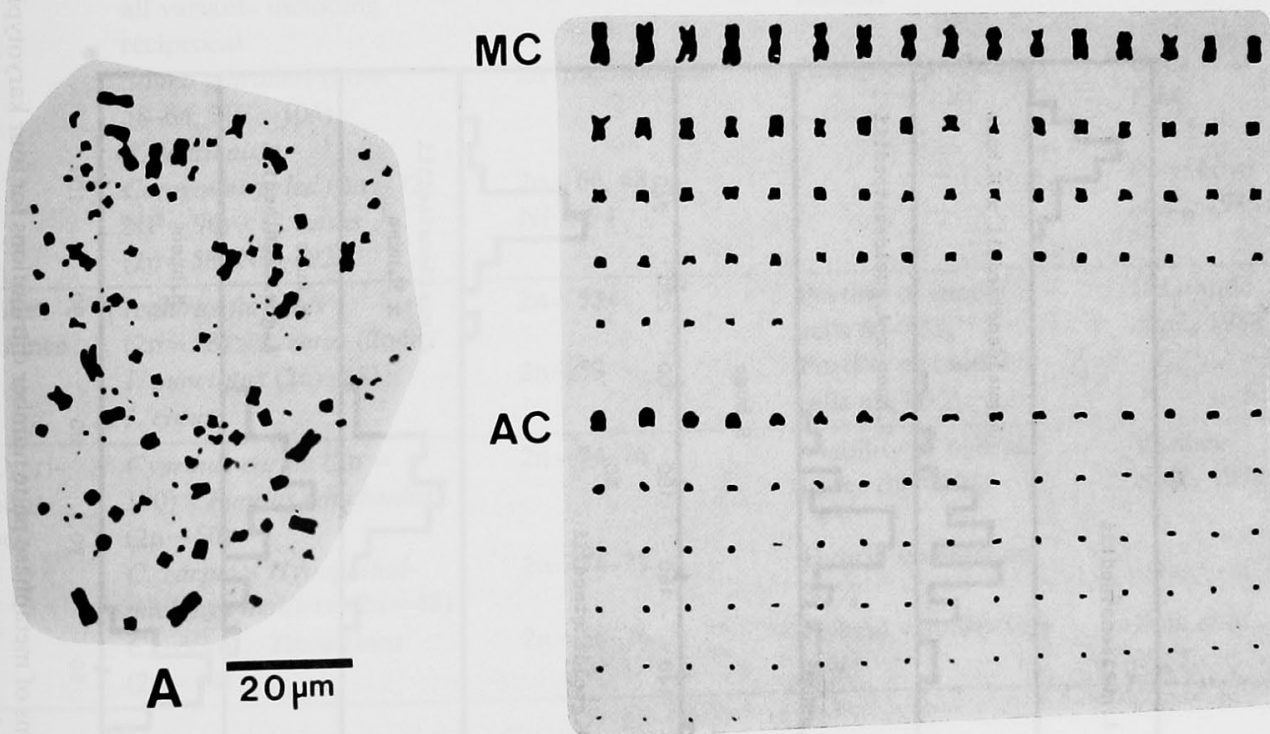

$A C$

B

Fig. 3. Metaphase plate (A) and karyogram (B) of hybrid between Russian sturgeon (Female) and great sturgeon (male): $2 n=153, \mathrm{NC}=69$.

chromosome appeared to be by 20 chromosomes lower than it was expected, and modes were not expressed in both hybrid variants. The same referred to MC (number of bi-armed chro- 


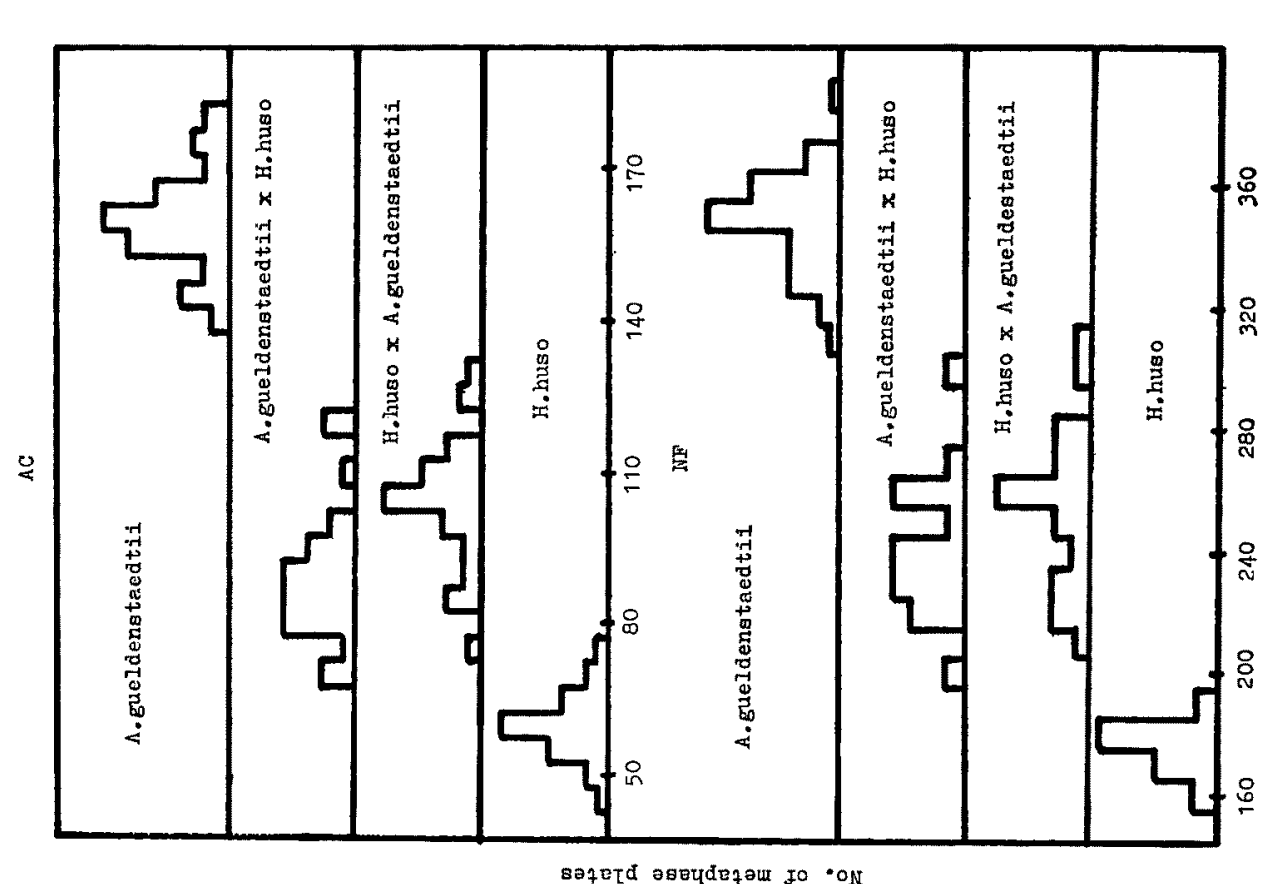

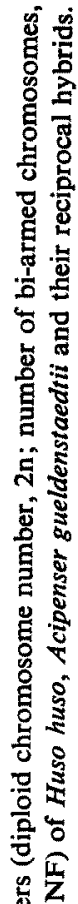

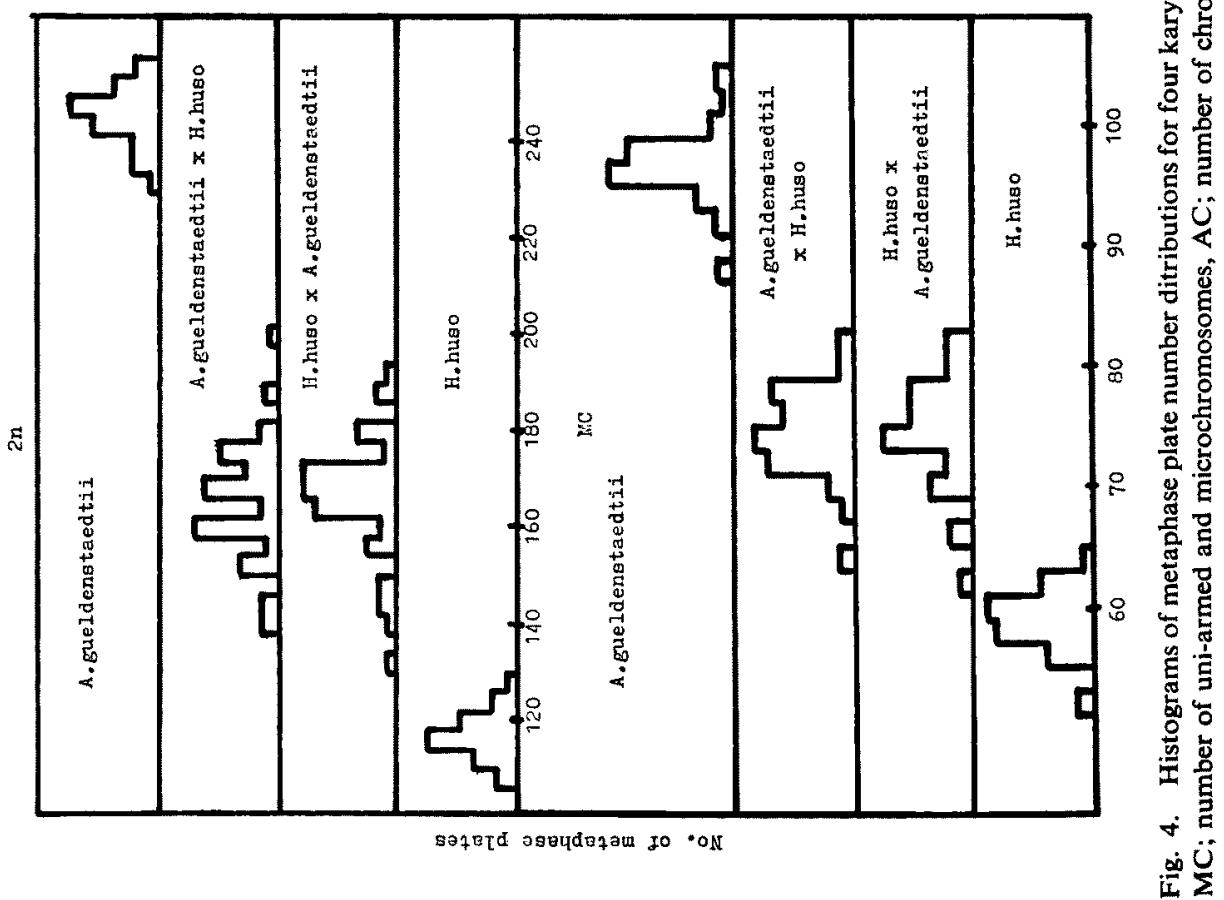


mosomes): it constituted about $74-75$ against 80 that was hypothetically expected. It is obvious that other quantitative parameters (numbers of uni-armed and microchromosomes, $\mathrm{AC}$; and number of chromosome arms, NF) are non-intermediate in the hybrids, too.

At the same time no authentical differences between the reciprocal hybrid forms were observed in all four karyotype parameters examined (Table 1). Moreover, homogeneity of

Table 2. Karyotype structure of hybrids from crosses between fishes with different chromosome numbers

\begin{tabular}{|c|c|c|c|c|}
\hline Order & $\begin{array}{l}\text { Parental species and } \\
\text { their karyotypes }\end{array}$ & $\begin{array}{c}\text { Hybrid } \\
\text { karyotype }\end{array}$ & $\begin{array}{l}\text { Additional } \\
\text { information }\end{array}$ & $\begin{array}{l}\text { Source of } \\
\text { reference }\end{array}$ \\
\hline \multirow[t]{9}{*}{$\begin{array}{l}\text { Salmoni- } \\
\text { formes }\end{array}$} & $\begin{array}{l}\text { Oncorhynchus keta }(2 \mathrm{n}=74, \\
\mathrm{NF}=100) \times O . \text { gorbuscha } \\
(2 \mathrm{n}=52, \mathrm{NF}=100)\end{array}$ & $\begin{array}{l}2 n=59-68, \text { mode } \\
\text { with } 2 n=64, \\
N F=100\end{array}$ & - & $\begin{array}{l}\text { Mitrophanov } \\
\text { et al., } 1977\end{array}$ \\
\hline & $\begin{array}{l}\text { O. masou } \\
(2 \mathrm{n}=66, \mathrm{NF}=100) \times \\
\text { O. gorbuscha }\end{array}$ & $\begin{array}{l}\text { Mode with } \\
2 \mathrm{n}=59\end{array}$ & $\begin{array}{l}\text { Sharp } 2 n \text { variability } \\
(2 n=50-102), \text { often } \\
\text { without mode }\end{array}$ & Arai, 1984 \\
\hline & $\begin{array}{l}\text { O. gasou } \times \text { Salvelinus } \\
\text { leucomaenis }(2 \mathrm{n}=84, \mathrm{NF}= \\
100) \text { in reciprocal variants }\end{array}$ & $\begin{array}{l}\text { Mode with } \\
2 n=75\end{array}$ & & \\
\hline & $\begin{array}{l}0 . \text { keta } \times 0 . \text { masou in } \\
\text { reciprocal variants }\end{array}$ & $\begin{array}{l}\text { Mode with } \\
2 \mathrm{n}=70\end{array}$ & Hybrids inviable & \\
\hline & $\begin{array}{l}\text { O. keta } \times \text { Salvelinus } \\
\text { fontinalis }(2 \mathrm{n}=84, \mathrm{NF}= \\
100) \text { in reciprocal variants }\end{array}$ & $\begin{array}{l}\text { Mode with } \\
2 n=79\end{array}$ & $\begin{array}{l}\text { High level of } \\
\text { aneuploidy; hybrid } \\
\text { viability very low }\end{array}$ & Arai, 1986 \\
\hline & $\begin{array}{l}\text { Salmo salar }(2 \mathrm{n}=58, \\
\mathrm{NF}=74), S . \text { trutta }(2 \mathrm{n}=80, \\
\mathrm{NF}=100), S . \text { fontinalis in } \\
\text { all variants including } \\
\text { reciprocal }\end{array}$ & $\begin{array}{l}2 \mathrm{n} \text { near } \\
\text { intermediate }\end{array}$ & $\begin{array}{l}\text { Very high variability } \\
\text { of } 2 \mathrm{n} \text { and bi-armed } \\
\text { chromosome number } \\
\text { number }\end{array}$ & $\begin{array}{l}\text { Gjedrem } \\
\text { et al., } 1977\end{array}$ \\
\hline & $\begin{array}{l}\text { Salmo gairdneri }(2 \mathrm{n}= \\
58-64, \mathrm{NF}=104) \times\end{array}$ & $2 n$ intermediate & Aneuploidy absent & $\begin{array}{l}\text { Ueda et al., } \\
1984\end{array}$ \\
\hline & S. fontinalis & & & \\
\hline & $\begin{array}{l}\text { Coregonus peled }(2 \mathrm{n}=72 \text {, } \\
\mathrm{NF}=96) \times C . \text { nasus } \\
(2 \mathrm{n}=58, \mathrm{NF}=92)\end{array}$ & $\begin{array}{l}2 \mathrm{n}=66,68 \\
\mathrm{NF}=94\end{array}$ & - & $\begin{array}{l}\text { Polyakova } \\
\text { et al., } 1983\end{array}$ \\
\hline $\begin{array}{l}\text { Siluri- } \\
\text { formes }\end{array}$ & $\begin{array}{l}\text { Icalurus furcatus } \\
(2 \mathrm{n}=58) \times I \text {. catus }(2 \mathrm{n} 48)\end{array}$ & $2 n=53$ & $\begin{array}{l}\text { Portion of modal } \\
\text { cells } 50-70 \%\end{array}$ & $\begin{array}{l}\text { LeGrande } \\
\text { et al., } 1984\end{array}$ \\
\hline & $\begin{array}{l}\text { I. punctatus }(2 \mathrm{n}=58) \times \\
\text { I. catus }\end{array}$ & $2 n=53$ & $\begin{array}{l}\text { Portion of modal } \\
\text { cells ap. } 40 \%\end{array}$ & \\
\hline \multirow[t]{3}{*}{$\begin{array}{l}\text { Cypri- } \\
\text { nifor- } \\
\text { nes }\end{array}$} & $\begin{array}{l}\text { Cyprinus carpio }(2 \mathrm{n}= \\
100) \times \text { Puntius conchonius } \\
(2 \mathrm{n}=50)\end{array}$ & $2 n=74-76$ & $\begin{array}{l}\text { Viability of hybrids } \\
\text { lower than } 50 \%\end{array}$ & $\begin{array}{l}\text { Vasiliev } \\
\text { et al., } 1978\end{array}$ \\
\hline & $\begin{array}{l}\text { C. carpio } \times \text { Hypophthal- } \\
\text { michthys molitrix }(2 \mathrm{n}=48)\end{array}$ & & $\begin{array}{l}\text { Hybrid viability ap. } \\
80 \%\end{array}$ & \\
\hline & $\begin{array}{l}\text { C. carpio } \times \text { Tinca tinca } \\
(2 \mathrm{n}=48)\end{array}$ & $2 n=68-76$ & $\begin{array}{l}\text { Hybrid viability very } \\
\text { low }\end{array}$ & $\begin{array}{l}\text { Sola et al., } \\
1983\end{array}$ \\
\hline
\end{tabular}

morphological structure of karyotypes does not allow the marker chromosome to be distinguished for identificaion of parental karyotypes in the hybrid genome. The only thing that attracts attention is that hybrid karyotype includes only 4 relatively large acrocentric chromosomes while karyotypes of Russian and great sturgeon feature 12 and 2 such elements, respectively, which can be another result of non-intermediate karyotype inheritance. 
$\Rightarrow \quad$ The sharp increase of coefficient of variation (C. V.) were observed in all quantitative karyotypic parameters in both hybrids (shown in Table 1): $\mathrm{P}<0.001$ for $2 \mathrm{n}, \mathrm{AC}, \mathrm{NF}$ and $\mathrm{P}<0.01$ for $\mathrm{MC}$. Such a high variability suggests high level of karyotype disbalancing, more considerable than that described in hybrids between the equal-chromosome species: in bester (Arefjev 1989), and in hybrid between the Russian and the Siberian sturgeons (Arefjev and Phillipova, unpubl. data). Positive correlation between karyotype destabilization and fertility decrease revealed from cytogenetic analysis of various acipenserid hybrids indicates complete sterility of both reciprocal hybrids between Russian and great sturgeon as the genetically unstable forms.

Mechanisms of chromosome set variability in the hybrid examined are evidently typical for acipenserids and their hybrids and are connected mainly with aneuploidy realized with

Table 3. Dimensions of erythrocytes of the Russian sturgeon, the great sturgeon, and their hybrids

\begin{tabular}{|c|c|c|c|c|c|c|}
\hline \multirow[t]{2}{*}{ Species, form } & \multicolumn{2}{|c|}{ Major axis $(\mu \mathrm{m})$} & \multicolumn{2}{|c|}{ Minor axis $(\mu \mathrm{m})$} & \multicolumn{2}{|c|}{ "Volume" $\left(\mu \mathrm{m}^{3}\right)$} \\
\hline & $\overline{\mathrm{x}}$ & C. V. & $\bar{x}$ & C. V. & $\ddot{x}$ & C. V. \\
\hline \multirow[t]{2}{*}{ Great sturgeon* } & $14.22 \pm 0.11$ & $5.7 \%$ & $9.63 \pm 0.07$ & $5.4 \%$ & $5523.8 \pm 72.6$ & $9.3 \%$ \\
\hline & $13.96 \pm 0.15$ & $7.7 \%$ & $9.78 \pm 0.10$ & $7.4 \%$ & $5593.1 \pm 96.5$ & $12.2 \%$ \\
\hline \multirow[t]{2}{*}{ Great $\times$ Russian } & $14.01 \pm 0.14$ & $7.3 \%$ & $11.12 \pm 0.11$ & $6.9 \%$ & $7256.7 \pm 125.2$ & $12.2 \%$ \\
\hline & $14.36 \pm 0.14$ & $6.4 \%$ & $10.80 \pm 0.12$ & $7.3 \%$ & $70.6 .0 \pm 105.2$ & $10.6 \%$ \\
\hline \multirow[t]{2}{*}{ Russian $\times$ great } & $14.28 \pm 0.18$ & $9.8 \%$ & $10.84 \pm 0.14$ & $9.8 \%$ & $7028.7 \pm 153.1$ & $15.4 \%$ \\
\hline & $14.57 \pm 0.16$ & $7.6 \%$ & $10.63 \pm 0.09$ & $5.8 \%$ & $6896.3 \pm 105.3$ & $10.8 \%$ \\
\hline \multirow[t]{2}{*}{ Russian sturgeon } & $17.58 \pm 0.19$ & $7.4 \%$ & $13.33 \pm 0.11$ & $5.5 \%$ & $13084.8 \pm 181.4$ & $9.8 \%$ \\
\hline & $17.39 \pm 0.23$ & $9.4 \%$ & $13.34 \pm 0.13$ & $6.7 \%$ & $12962.8 \pm 254.8$ & $13.9 \%$ \\
\hline
\end{tabular}

* for each form the data from two specimens are given

Table 4. Dimensions of erythrocyte nuclei of the Russian sturgeon, the great sturgeon, and their hybrids

\begin{tabular}{|c|c|c|c|c|c|c|}
\hline \multirow{2}{*}{ Species, form } & \multicolumn{2}{|c|}{ Major axis $(\mu \mathrm{m})$} & \multicolumn{2}{|c|}{ Minor axis $(\mu \mathrm{m})$} & \multicolumn{2}{|c|}{ "Volume" $\left(\mu \mathrm{m}^{3}\right)$} \\
\hline & $\overrightarrow{\mathrm{x}}$ & C. $V$. & $\overline{\mathrm{x}}$ & C. V. & $\overline{\mathrm{x}}$ & C. $\mathrm{v}$. \\
\hline \multirow[t]{2}{*}{ Great sturgeon } & $6.21 \pm 0.07$ & $8.2 \%$ & $4.33 \pm 0.06$ & $10.1 \%$ & $487.7 \pm 9.6$ & $13.9 \%$ \\
\hline & $6.18 \pm 0.10$ & $11.2 \%$ & $4.26 \pm 0.06$ & $9.4 \%$ & $469.8 \pm 11.2$ & $16.8 \%$ \\
\hline \multirow[t]{2}{*}{ Great $\times$ Russian } & $6.68 \pm 0.09$ & $10.2 \%$ & $5.17 \pm 0.06$ & $8.4 \%$ & $747.9 \pm 13.6$ & $12.9 \%$ \\
\hline & $6.54 \pm 0.07$ & $7.7 \%$ & $5.02 \pm 0.07$ & $9.3 \%$ & $690.4 \pm 13.8$ & $14.1 \%$ \\
\hline \multirow[t]{2}{*}{ Russian $\times$ great } & $6.45 \pm 0.11$ & $12.2 \%$ & $4.96 \pm 0.08$ & $11.9 \%$ & $664.7 \pm 19.3$ & $20.5 \%$ \\
\hline & $6.72 \pm 0.08$ & $8.0 \%$ & $4.87 \pm 0.06$ & $9.1 \%$ & $667.6 \pm 11.8$ & $12.5 \%$ \\
\hline \multirow[t]{2}{*}{ Russian sturgeon } & $8.46 \pm 0.12$ & $9.7 \%$ & $6.30 \pm 0.08$ & $9.5 \%$ & $1406.5 \pm 33.8$ & $17.0 \%$ \\
\hline & $8.27 \pm 0.09$ & $8.0 \%$ & $6.21 \pm 0.07$ & $8.4 \%$ & $1325.9 \pm 25.5$ & $13.6 \%$ \\
\hline
\end{tabular}

microchromosomes (Arefjev 1989a). Besides, this hybrid demonstrates considerable increase in variability of bi-armed chromosome number MC: such an increase is not recorded in all three bester generations. This fact reflecting aneuploidy on bi-armed chromosomes is an additional proof for considerable karyotypic disbalancing of hybrid genome.

Data of karyotypic analysis of interspecific fish hybrids obtained from crossing between species with different $2 \mathrm{n}$ numbers are presented in Table 2 ; such data are available mainly on salmonids. In the majority of cases aneuploidy occurs, the degree of which may correlate with fertility rate observed in hybrids (Arai 1984). Howevet, modes of $2 \mathrm{n}$, though not always distinctly pronounced, are often intermediate in realtion to $2 \mathrm{n}$ parental karyotypes, with the exception of chromosome cemplements of hybrid between two cicoes, family Coregonidae 
(Polyakova et al. 1983), where $2 \mathrm{n}$ is higher then intermediate value, and hypomodal karyotype of hybrid between carp and tench (Sola et al. 1983).

Non-intermediate inheritance of chromosome number is occasionally noted in other groups of animal, for example, in hybrids between Drosophila nasuta nasuta $(2 \mathrm{n}=6)$ and $D$. $n$. albomicana $(2 n=8)$ which shows $2 n=6$ and $2 n=7$ (Ramachandra and Ranganath 1986). On the whole, rarity of non-intermediate karyotype patterns indicates high degree of karyotypic destabilization of such hybrids and consequently their complete sterility and, in some cases, low viability.

Genome size (moreover, chromosome number) can be estimated indirectly, in particular, by cell size measurements, and the analysis of erythrocyte dimensions appears to be the most expedient. Data of such measurements are shown in Tables 3 and 4. "Volumes" of erythrocytes and their nuclei are calculated from the equation $V=4 / 3 \pi \cdot a \cdot b^{2}$, where $a$ and $b$ are major and minor axis length.

None of the forms is distinguishes from other in terms of C. V. of all characters: they are likely to be too "rough" to reflect increasing aneuploidy of hybrid karyotype. At the same time average values of erythrocyte and nucleus linear sizes of great sturgeon and hybrids do not considerably differ, while erythrocytes of Russian sturgeon are prominently larger (Fig. 5). Such a difference is evidently conditioned by di-tetraploid relationship between these species. In particular, this correlation is used for indirest testing of ploidy level in salmonids based on erythrocyte dimension measurement (Benfey and Sutterlin 1984). This method may be recommended for similar experiments on acipenserids in the U. S. S. R..

By erythrocyte and nucleus volume the hybrids are evidence for a displacement of patterns towards those of the great sturgeon, which can serve as confirmation of non-intermediate inheritance of genome structure in

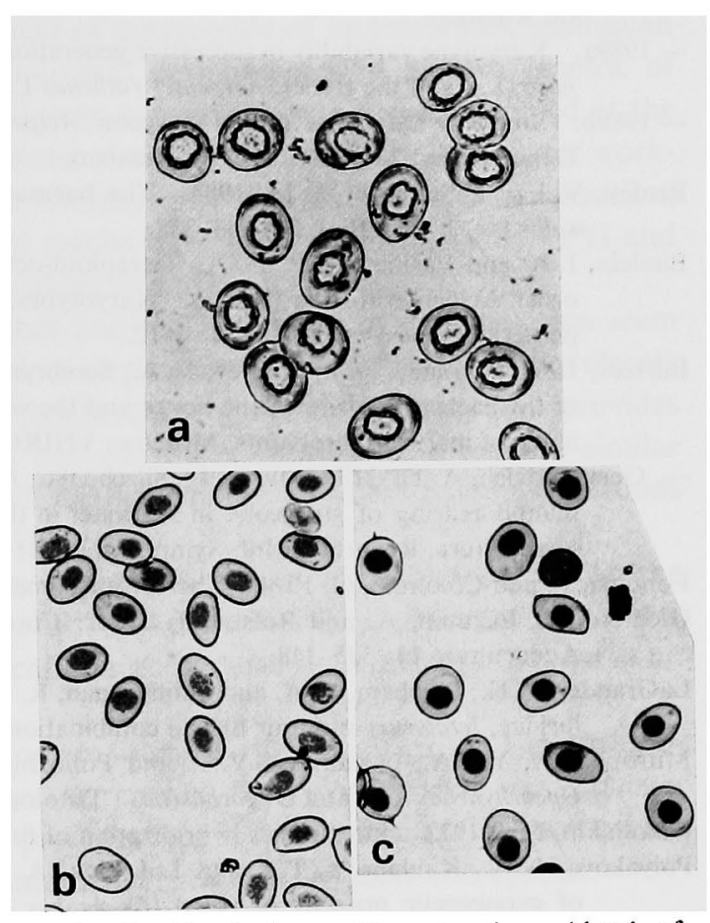

Fig. 5. Circulating erythrocytes from blood of Acipenser gueldenstaedtii (a), Huso huso (b), and their hybrid (c). the hybrid examined.

Thus, tha data presented demonstrate 'strong destabilization of genetic apparatus in hybrid between the great and the Russian sturgeon quantitatively being the highest among karyotyped acipenserids and their hybrids. It is precisely this fact that allows for prediction of complete sterility of this hybrid.

The authors thank Dr. J, Stanley for critical reviewing of the manuscript.

\section{Summary}

Hybrids between the great sturgeon and the Russian sturgeon in reciprocal crosses are found to exhibit non-intermediete chromosome number, $2 n=167-169$, on average. The hybrids are also characterized by sharp increase in variability of the quantitative karyotypic parameters such as diploid chromosome number, bi-armed chromosome number, number of 
uni-armed and microchromosomes, and chromosome arm number. Measurements of erythrocytes and their nuclei confirmed the di-tetraploid relationship of the parental species and non-intermediate pattern of the hybrid genome. Sharp disbalancing of karyotype of both reciprocal hybrids is indicative of high probability of their complete sterility.

\section{References}

Arai, K. 1984. Developmental genetic studies on salmonids: morphogenetics, isozyme phenotypes and chromosomes in hybrid embryos. Mem. Fac. Fish. Hokkaido Univ. 31: 1-84.

- 1986. Effect allotriploidization on development of the hybrids between female chum salmon and male brook trout. Bull. Jap. Soc. Sci. Fish. 52: 823-830.

Arefjev, V. A. 1988. Cytogenetic monitoring of acipenserid hybridization. Diss. Thesis, Moscow, 24 pp. (in Russian).

- 1989a. Karyotype variability in successive generations after hybridization between the great sturgeon, Huso huso (L.), and the sterlet, Acipenser ruthenus L. J. Fish Biol. 35: 819-828 (in Russian).

- 1989b. Study of karyotype of the sturgeon Acipenser gueldenstaedtii Brandt (Chondrostei). Tsitol. y Genet. (Kiev) 23 (n. 4): 7-10 (in Russian).

Benfey, V. J. and Sutterlin, A. M. 1984. The haematology of triploid landlocked Atlantic salmon, Salmo salar L. J. Fish Biol. 24: 333-338.

Birstein, I. A. and Vasiliev, V. P. 1987. Tetraploid-octaploid relationships and karyological evolution in the order Acipenseriformes (Pisces). Karyotypes, nucleoli and nucleolus-organizer regions in four ačipenserid species. Genetica 72: 3-12.

Burtzev, I. A., Nikolaev, A. I., Arefjev, V. A., Serebryakova, E. V. and Slizchenko, A. G. 1988. Pecularities of the backcross forms of the bester and the ways of selection utilizing these forms. In: Genetic analysis of marine hydrobionts, Moscow: VNIRO: 143-156 (in Russian).

-, Gershanovich, A. D., Nikolaev, A. I., Slizchenko, A. G. and Filippova, O. P. 1989. Results of experimantal rearing of sturgeons in sea water in the North Eastern Black Sea. In: Modern Problems in Mariculture, Reports on Int. Symp., Moscow: VNIRO: 108-109 (in Russian).

Fontana, F. and Colombo, G. 1974. The chromosomes of Italian sturgeons. Experientia 30: 739-742.

Gjedrem, T., Egguum, A. and Refstie, T. 1977. Chromosomes of some salmonids and salmonid hybrids. Aquaculture 11 : 335-348.

LaGrande, W. H., Dunham, R. A. and Smitherman, R. O. 1984. Karyology of three species of catfishes (Ičtaluridae, Ictalurus) and four hybrid combinations. Copeia N 4: 873-878.

Mitrophanov, Yu, A., Otradnova, V. V. and Pohozhij, N. V. 1977. On the karyotype of hybrid between Oncorhynchus keta and O. gorbuscha. Tsitologia (Leningrad) 19: 798-808 (in Russian).

Nikoljukin, N. I. 1972. Interspecies hybridization of fish. Moscow: Uauka, 337 pp. (in Russian),

Polyakova, L. A., Kaidanova, T. I. and Lokshina, A. B. 1983. Cytokaryological and biochemical analysis of gynogenetic progeny of peled (Coregonus peled $\mathrm{Gm}$.) during radiation gynogenesis (C. peled $\mathrm{X}$ C. nasus). In: Sbornik trudov Gos NTORH, Leningrad, Vol. 203: 24-29 (in Russian).

Ramachandra, N. B. and Ranganath, H. A. 1986. The chromosomes of two Drosophila races: D. nasuta nasuta and $D$. nasuta albomicana. IV. Hybridization and karyotype repatterning. Chromosoma 93: 243-248.

Rivlin, K., Rachlin, J. W. and Dale, G. 1985. A simple method for the preparation of fish chromosomes applicable to field work, teaching and banding. J. Fish Biol. 26: 267-272.

Sola, L., Cataudella, S., Gentili, G. and Monaco, G. 1983. An experimental carp $\times$ tench hybrid: karyological analysis and SEM morphological observations. Boll. Zool. 50: 159-171.

Ueda, T., Ojima, Y., Sato, R. and Fukuda, Y. 1984. Triploid hybrids between female rainbow trout and male brook trout. Bull. Jap. Soc. Sci. Fish. 50: 1331-1336.

Vasiliev, V. P. 1985. Evolutionary karyology of fishes. Moscow: Nauka, 333 pp. (in Russian).

-, Makeeva, A.P. and Rjabov, N. I. 1978. Karyotypes of some cyprinids and their hybrids. Genetika (Moscow) 14: 1453-1460 (in Russian).

- and Sokolov, L. I. 1980. The method for studying of chondrostean karyotypes. Tsitologia (Leningrad) 22: 1106-1109 (in Russian).

Yu, X., Zhou Tun, Li Kang, Li Youcheng and Zhou Mi. 1987. On the karyosystematics of cyprinid fishes and a summary of fish"chromosome studies in China. Genetica 72: 225-236. 